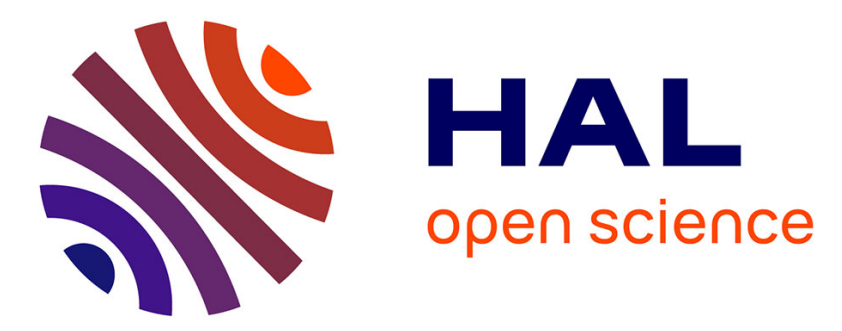

\title{
PSGR olfactory receptor: A new potential target in pulmonary arterial hypertension
}

Audrey Courboulin, Marceau Quatredeniers, Guenhaël Sanz, Sandra

Breuils-Bonnet, Matthieu Vocelle, Mathilde Lafond, Frédéric Perros, Sébastien Bonnet, Edith Pajot-Augy, Marc Humbert, et al.

\section{To cite this version:}

Audrey Courboulin, Marceau Quatredeniers, Guenhaël Sanz, Sandra Breuils-Bonnet, Matthieu Vocelle, et al.. PSGR olfactory receptor: A new potential target in pulmonary arterial hypertension. ERS International Congress 2016, Sep 2016, Londres, United Kingdom. 10.1183/13993003.congress2016.PA2475 . hal-02743621

\section{HAL Id: hal-02743621 \\ https://hal.inrae.fr/hal-02743621}

Submitted on 3 Jun 2020

HAL is a multi-disciplinary open access archive for the deposit and dissemination of scientific research documents, whether they are published or not. The documents may come from teaching and research institutions in France or abroad, or from public or private research centers.
L'archive ouverte pluridisciplinaire HAL, est destinée au dépôt et à la diffusion de documents scientifiques de niveau recherche, publiés ou non, émanant des établissements d'enseignement et de recherche français ou étrangers, des laboratoires publics ou privés.

\section{(c)(1)}

Distributed under a Creative Commons Attribution| 4.0 International License 


\section{PSGR olfactory receptor: A new potential target in pulmonary arterial hypertension}

Audrey Courboulin, Marceau Quatredeniers, Guenhaël Sanz, Sandra Breuils-Bonnet, Matthieu Vocelle, Mathilde Lafond, Frédéric Perros, Sébastien Bonnet, Edit ] European Respiratory Journal 2016 48: PA2475; DOI: 10.1183/13993003.congress-2016.PA2475
Article
Info \&
Metrics

ARTICLE INFORMATION

vol. 48 no. suppl 60

DOI

https://doi.org/10.1183/13993003.congress2016.PA2475

Published By European Respiratory Society

Print ISSN $\quad$ 0903-1936

Online ISSN 1399-3003

History Published online November 8, 2016.

Copyright \& Usage Copyright @the authors 2016

\section{AUTHOR INFORMATION}

Audrey Courboulin ${ }^{1}$, Marceau Quatredeniers ${ }^{1}$, Guenhaël Sanz ${ }^{3}$, Sandra Breuils-Bonnet ${ }^{2}$, Matthieu Vocelle ${ }^{1}$, Mathilde Lafond ${ }^{1}$, Frédéric

Perros $^{1}$, Sébastien Bonnet ${ }^{2}$, Edit Pajot-Augy ${ }^{3}$, Marc Humbert ${ }^{1,4}$ and Sylvia Cohen-Kaminsky

${ }^{1}$ Univ Paris-Sud, Université Paris-Saclay, Inserm UMR-S999, Le Plessis Robinson, France

${ }^{2}$ Groupe de Recherche en Hypertension Artérielle Pulmonaire, CRIUCPQ, Quebec, Canada

${ }^{3}$ UR1197, Unité de Neurobiologie de l'Olfaction (NBO), Jouy-en-Josas, France ${ }^{4}$ AP-HP, Hôpital Bicêtre, Le Kremlin Bicêtre, France 


\section{PSGR olfactory receptor: A new potential target in pulmonary arterial hypertension}

Audrey Courboulin, Marceau Quatredeniers, Guenhaël Sanz, Sandra Breuils-Bonnet, Matthieu Vocelle, Mathilde Lafond, Frédéric Perros, Sébastier European Respiratory Journal 2016 48: PA2475; DOI: 10.1183/13993003.congress-2016.PA2475

$$
\text { Article }
$$

$$
\text { Info \& Metrics }
$$

\section{Abstract}

Pulmonary arterial hypertension $(\mathrm{PAH})$ is a rare progressive disease due to distal vascular remodeling, leading to right heart failure and death. PSGR is an olfactory receptor (OR) that has been recently detected in peripheral tissues. Moreover, PSGR overexpression is associated with pro-proliferative phenotype in prostate cancer. Since PAH vascular cells are characterized by cancer-like over-proliferation, we hypothesized that PSGR might participate in the vascular remodeling leading to $\mathrm{PAH}$.

Here we aimed to determine whether upregulation of PSGR is implicated in PAH pathological phenotype, and to explore PSGR as a novel therapeutic target in PAH.

PSGR gene and protein expressions were assessed in total lung, distal pulmonary arteries and Pulmonary Artery Smooth Muscle Cells (PASMC) and Endothelial Cells from PAH patients and controls using qRT-PCR and western blot. We evaluated proliferation and apoptosis using Ki67 and TMRM. siRNAdirected silencing of PSGR and STAT3, was used to inhibit the specific expression in PASMCs, whereas PP2 was used to inhibit Src activation.

We demonstrate that PSGR expression is significantly increased in PASMCs and isolated pulmonary arteries of $\mathrm{PAH}$ patients. We also show a trend to decreased Src activation and restored BMPR2 expression as a function of PSGR inhibition in PAH-PASMC. Moreover, inhibition of STAT3 and/or Src partially decreased PSGR mRNA expression. PSGR silencing reversed the PAH pro-proliferative phenotype in human PASMC.

To conclude, overexpression of PSGR leads to a pro-proliferative phenotype of PASMCs in PAH, which could be decreased by PSGR inhibition. Src-STAT3 pathway activation is potentially the bridge linking PSGR and the pathophysiology. 